\title{
STUDI TENTANG KEPADATAN, KELIMPAHAN DAN POLA PENYEBAR IKAN LAYUR (Trichiurus lepturus L) PADA PERAIRAN DESA PASSO TELUK BAGUALA AMBON
}

\author{
Pieter Siahaya ${ }^{1}$ dan Dominggus Rumahlatu² \\ ${ }^{1}$ Alumni Program Studi Pendidikan Biologi \\ ${ }^{2}$ Dosen Program Studi Pendidikan Biologi \\ E-mail: minggus_rumahlatu@yahoo.com
}

\begin{abstract}
Background: Fish layur which is often called the people of Maluku as Fish Parang-parang is included order Perciformes in the Trchiuridae family and genus Trichiurus. The existence of fish in the waters Layur Passo not known with certainty.

Methods: The study took place in October 2014. The study was divided into three locations of the research station. The method used in this study are visual census to calculate directly the large number of fish caught at the sites. Then the data were analyzed descriptively. Calculations used in the processing of the data using the formula of density, abundance, and distribution patterns. Environmental characteristics in measuring temperature, salinity, $\mathrm{pH}$, and dissolved oxygen (DO).

Results: The results showed that the water environmental condition Passo village is quite good for the survival of the organism.

Conclusion: The density, abundance, and distribution pattern of fish layur relatively abundant in these waters with the highest value contained at two stations at the sites.
\end{abstract}

Keywords: Density, abundance, distribution patterns, Fish Layur.

\begin{abstract}
Abstrak
Latar Belakang: Ikan layur yang sering disebut masyarakat Maluku sebagai Ikan Parang-parang merupakan ordo Perciformes yang masuk dalam family Trchiuridae dan genus Trichiurus. Keberadaan Ikan Layur di kawasan perairan Passo belum diketahui dengan pasti.

Metode: Penelitian ini berlangsung pada bulan Oktober tahun 2014. Penelitian ini dibagi atas tiga titik lokasi stasiun penelitian. Metode yang digunakan dalam penelitian ini bersifat sensus visual dengan menghitung secara langsung banyaknya jumlah ikan yang tertangkap di lokasi penelitian. Kemudian data yang diperoleh dianalisis secara deskriptif. Perhitungan yang digunakan dalam pengolahan data menggunakan rumus kepadatan, kelimpahan, dan pola sebaran. Karakteristik lingkungan yang di ukur adalah suhu, salinitas, $\mathrm{pH}$, dan oksigen terlarut (DO).

Hasil: Hasil penelitian menunjukkan bahwa kondisi lingkungan perairan Desa Passo tergolong baik untuk kelangsungan hidup organisme.

Kesimpulan: Kepadatan, kelimpahan, dan pola sebaran ikan layur di perairan tersebut tergolong melimpah dengan nilai tertinggi terdapat pada dua stasiun di lokasi penelitian.
\end{abstract}

Kata kunci: Kepadatan, Kelimpahan, Pola Sebaran, Ikan Layur. 


\section{PENDAHULUAN}

Kawasan perairan Maluku disekitar perairan Passo Kecamatan Teluk Baguala, merupakan wilayah pesisir yang memiliki ekosistem beragam, sehingga mmenyimpan sumber daya pesisir dan laut baik ikan maupun non ikan yang cukup tinggi. Kawasan perairan ini memiliki berbagai jenis biodata laut, salah satunya ikan layur atau yang sering dikatakan sebagian besar masyarakat Maluku sebagai lkan Parangparang. Ikan ini merupakan organisme akuatik yang rentan terhadap perubahan lingkungan, Terutama yang di akibatkan oleh aktivitas manusia secara langsung maupun tidak langsung. Limbah-limbah buangan yang dihasilkan oleh berbagai aktivitas manusia turut mempengaruhi kualitas perairan baik fisik, kimia, maupun biologis. Faktor fisik kimia yang mempengaruhi suatu perairan antaralain kedalaman, suhu, salinitas, kandungan oksigen terlarut dan derajat keasaman. Faktor biologi yang berpengaruh adalah komposisi kenis hewan dalam perairan yakni produsen yang merupakan sumber makanan bagi hewan tersebut (Romimohtarto dan Juana, 2001).

Kelestarian dari tiap ekosistem akan sangat mempengaruhi tingkat kepadatan dan kelimpahan spesies ikan di suatu wilaya. Pemahaman tentang kondisi ekosistem di wilayah pesisir dan pantai serta tersedianya data yang lengkap tentang keanekaragaman biota (khususnya ikan) pada suatu wilayah akan mampu menjadi acuan pengelolaan wilayah pesisir dan pantai khususnya di bidang perikanan laut. Beberapa kelompok ikan termaksud ikan layur menunjukan kecenderungan kepadatan dan pola sebaran yang meningkat untuk jangka waktu yang panjang pada kondisi lingkungan dengan presentase kondisi perairan yang baik (Suharti, 2013).

Ikan layur yang sering disebut masyarakat Maluku sebagai Ikan Parangparang merupakan ordo Perciformes yang masuk dalam family Trchiuridae dan genus Trichiurus keberadaan Ikan Layur di kawasan perairan Passo belum diketahui dengan pasti, sehingga diperlukan upayaupaya untuk mengungkapkan keberadaan komunitas ikan layur di kawasan ini.

Oleh sebab itu, perlu dilakukan penelitian tentang kepadatan, kelimpahan ikan layur pada perairan Desa Passo Teluk
Baguala Ambon yang merupakan derah penting bagi nelayan setempat karena telah lama dijadikan sebagai areal penangkapan sumber daya hayati perikanan untuk kebutuhan pangan, daerah pemukiman masyarakat dan berbagai aktivitas masyarakat lainnya.

\section{METODE}

Penelitian ini merupakan penilitian sensus visual, yakni dengan melakukan pendataan dengan menghitung secara langsung di lapangan terhadap banyaknya jumlah ikan yang tertangkap dan kemudian di lanjutkan dengan perhitungan menggunakan rumus kepadatan, kepadatan relatif dan pola sebaran. Penelitian ini dilaksanakan pada bulan Oktober 2014. Pengambilan sampel ikan bertempat di perairan pantai Passo Teluk Baguala. Sampel dalam penelitian ini yaitu seluruh ikan layur yang tertangkap pada masingmasing stasiun penelitian di perairan Desa Passo. Alat yang digunakan dalam penelitian ini yaitu perahu, gillnet dasar, thermometer, pH-meter, refraktometer, kamera digital, mistar ukur, jarring pantai, dan alat tulis menulis serta coolbox untuk wadah penampung ikan.

Pengambilan sampel ikan dilakukan dengan menggunakan jaring pantai yang memiliki panjang jaring $720 \mathrm{~m}$ dengan lebar jaring $4,5 \mathrm{~m}$ dan ukuran mata jaring $4,45 \mathrm{~cm}$. Kedalaman perairan tempat penarikan jaring bervariasi sekitar $10 \mathrm{~m}$ tergantung kondisi lokasinya. Sampel ikan diambil dengan tiga kali ulangan pada setiap stasiun. Pengoperasian jaring pantai dilakukan oleh tiga orang pada tiga titik yang digunakan sebagai lokasi penelitian. Setiap spesies ikan layur yang tertangkap dikumpulkan kemudian dihitung. Data yang diperoleh dianalisis secara deskriptif melalui hasil perhitungan dengan rumus kepadatan populasi, kepadatan relative, kelimpahan, dan pola sebaran jenis.

\section{HASIL DAN PEMBAHASAN}

1. Deskripsi Data Hasil Penelitian.

a. Parameter Lingkungan Pada Lokasi Penelitian

Parameter lingkungan merupakan salah satu faktor penting dalam penelitian ini. 
Parameter lingkungan baik factor fisik maupun factor kimia yang diambil pada penelitian ini adalah suhu, salinitas, $\mathrm{pH}$, dan Oksigen Terlarut (DO) di periran lokasi pengambilan sampel.Penelitian ini dilakukan pada bulan september 2014 hingga bulan oktober 2014, dengan kondisi perairan Desa Passo memiliki kisaran suhu antara 29$29,60^{\circ} \mathrm{C}$, nilai Salinitas berkisar antara 10 -
$10,89 \%$, nilai $\mathrm{pH}$ untuk setiap stasiun berkisar antara8-8,72, dan nilai oksigen terlarut untuk setiap stasiun berkisar antara 3-4 mg/l sperti yang terlihat pada tabel 4.1. Pengukuran pada factor lingkungan ini dilakukan bersamaan dengan pengumpulan data Trichiurus lepturus $\mathrm{L}$ pada ketiga stasiun penelitian.

Tabel 1. Data Parameter Lingkungan Pada Lokasi Penelitian.

\begin{tabular}{ccccc}
\hline Stasiun & Suhu $\left({ }^{\circ} \mathbf{C}\right)$ & Salinitas (\%) & pH & DO (mg/l) \\
\hline I & 29,04 & 27,60 & 7,08 & 8,01 \\
II & 29,60 & 29,89 & 8,00 & 10,5 \\
III & 29,5 & 25,75 & 7,23 & 8,06 \\
\hline
\end{tabular}

Berdasarkan hasil penelitian diatas terdapat perbedaan kondisi lingkungan di tiga stasiun lokasi penelitian tersebut. Perbedaan tersebut yakni meliputu perbedaan suhu, salinitas, $\mathrm{pH}$, dan oksigen terlarut. Suhu suatu badan air dipengaruhi oleh musim, lintang, ketinggian dari permukaan laut, waktu dalam satu hari, sirkulasi udara, penutupan awan, airan serta kedalaman dari badan air (Effendi, 2003). Menurut Desmukh dalam Abubakar (2011), perairan pantai tropika biasanya mempunyai kisaran suhu antara $27-29^{\circ} \mathrm{C}$, akan tetapisuhu ini akan meningkat sesuai dengan berkurangnya kedalaman air selanjutnya, Mukhtasor (2007), mengungkapkan bahwa biasanya suhu air laut berkisar antara -2 sampai $30^{\circ} \mathrm{C}$ dan suhu yang baik untuk kehidupan organisme adalah $18-30^{\circ} \mathrm{C}$ dengan demikian, dapat dikatakan bahwa suhu di perairan Desa Passo yang merupakan lokasi penelitian masih sangat baik dan dapat mendukung kehidupan organisme yang ada di dalamnya.

Terkait dengan faktor salinitas, hal yang berpengaruh pada salinitas adalah curah huja, seperti yang di kemukakan oleh Nontji dalam Abubakar (2011), bahwa salinitas perairan menjadi turun karena dipengaruhi oleh curah hujan dan aliran sungai, sebaliknya daerah dengan penguapan yang kuat menyebabkan salinitas meningkat. Menurut Romimohtarto (2001), kisaran pH yang baik untuk mendukung kehidupan organisme perairan yaitu sekitar 6-8. Hal ini berarti bahwa nilai $\mathrm{pH}$ dan salinitas di perairan Desa Passo tergolong baik dan cukup optimal untuk kelangsungan hidup organisme didalamnya. Sedangkan untuk faktor kadar oksigen terlarut menurut Effendi (2003), perairan yang baik untuk perikanan sebaiknya memiliki kadar oksigen terlarut tidak kurang dari $5 \mathrm{ml} / \mathrm{L}$ oleh karena itu kadar oksigen terlarut pada lokasi perairan Desa Passo memiliki kisaran yang baik pula bagi kelangsungan hidup organisme.

\section{b. Hasil Penangkapan Trichiurus lepturus L Pada Lokasi Penelitian.}

Berdasarkan hasil penelitian yang telah dilakukan, maka diperoleh hasil penangkapan ikan layur (Trichiurus lepturus L) pada 3 stasiun penelitian di perairan pantai Desa Passo adalah sebagai berikut:

Tabel 2. Data Jumlah Individu Serta Total Rata-Rata Hasil Penangkapan Ikan Layur Trichiurus lepturus L Yang Tertangkap Pada Stasiun I.

\begin{tabular}{|c|c|c|c|c|}
\hline \multirow[b]{2}{*}{ Jenis Ikan } & \multicolumn{3}{|c|}{ Stasiun I } & \multirow[b]{2}{*}{$\begin{array}{c}\text { Total } \\
\text { Individu }\end{array}$} \\
\hline & $\begin{array}{c}\text { Hari } \\
\text { Pertama }\end{array}$ & $\begin{array}{c}\text { Hari } \\
\text { Kedua }\end{array}$ & $\begin{array}{c}\text { Hari } \\
\text { Ketiga }\end{array}$ & \\
\hline Trichiurus lepturus L & $\begin{array}{c}390 \\
\text { Individu }\end{array}$ & $\begin{array}{c}200 \\
\text { Individu }\end{array}$ & $\begin{array}{c}130 \\
\text { Individu }\end{array}$ & $\begin{array}{c}720 \\
\text { Individu }\end{array}$ \\
\hline
\end{tabular}


Tabel 3. Data Jumlah Individu Serta Total Rata-Rata Hasil Penangkapan Ikan Layur Trichiurus lepturus L Yang Tertangkap Pada Stasiun II.

\begin{tabular}{|c|c|c|c|c|}
\hline \multirow[b]{2}{*}{ Jenis Ikan } & \multicolumn{3}{|c|}{ Stasiun II } & \multirow[b]{2}{*}{$\begin{array}{c}\text { Total } \\
\text { Individu }\end{array}$} \\
\hline & $\begin{array}{c}\text { Hari } \\
\text { Pertama }\end{array}$ & $\begin{array}{c}\text { Hari } \\
\text { Kedua }\end{array}$ & $\begin{array}{c}\text { Hari } \\
\text { Ketiga }\end{array}$ & \\
\hline Trichiurus lepturus L & $\begin{array}{c}650 \\
\text { Individu }\end{array}$ & $\begin{array}{c}520 \\
\text { Individu }\end{array}$ & $\begin{array}{c}200 \\
\text { Individu }\end{array}$ & $\begin{array}{c}1370 \\
\text { Individu }\end{array}$ \\
\hline
\end{tabular}

Tabel 4. Data Jumlah Individu Serta Total Rata-Rata Hasil Penangkapan Ikan Layur Trichiurus lepturus L Yang Tertangkap Pada Stasiun III.

\begin{tabular}{|c|c|c|c|c|}
\hline \multirow[b]{2}{*}{ Jenis Ikan } & \multicolumn{3}{|c|}{ Stasiun III } & \multirow{2}{*}{$\begin{array}{c}\text { Total } \\
\text { Individu }\end{array}$} \\
\hline & $\begin{array}{c}\text { Hari } \\
\text { Pertama }\end{array}$ & $\begin{array}{c}\text { Hari } \\
\text { Kedua }\end{array}$ & $\begin{array}{c}\text { Hari } \\
\text { Ketiga }\end{array}$ & \\
\hline Trichiurus lepturus L & $\begin{array}{c}520 \\
\text { Individu }\end{array}$ & $\begin{array}{c}300 \\
\text { Individu }\end{array}$ & $\begin{array}{c}320 \\
\text { Individu }\end{array}$ & $\begin{array}{c}1140 \\
\text { Individu }\end{array}$ \\
\hline
\end{tabular}

Berdasarkan data di atas dapat dilihat bahwa ternyata hasil penangkapan ikan Trichiurus lepturus $\mathrm{L}$ pada ketiga stasiun memiliki hasil yang bervariasi. Tabel 3 menunjukan jumlah penangkapan ikan terbanyak yaitu 1370 individu ditemukan pada stasiun II dan tabel 2 yang menunjukan jumlah penangkapan ikan paling sedikit yaitu 720 individu pada stasiun I. Adanya variasi hasil penangkapan menunjukan adanya perbedaan jumlah kepadatan, kelimpahan serta pola distribusi yang berbeda-beda pada tiap stasiun penangkapan.

Berdasarkan data hasil penangkapan pada ketiga stasiun di atas maka kepadatan jumlah kepadatani, kelimpahan serta pola distribusi pada tiap stasiun dapat dihitung menggunakan rumus (Brower and Zar dalam Alfitriatussulus, 1989).

c. Hasil Perhitungan Kepadatan dan Kepadatan Relatif Trichiurus lepturus L.

Tabel 5, yaitu nilai hasil perhitungan kepadatan dan kepadatan relatif pada lokasi penelitian yaitu Perairan Pantai Desa Passo, diperoleh nilai kepadatan tertinggi ada pada stasiun II dengan nilai kepadatan yaitu 1,90. Begitu pula untuk nilai kepadatan relatif, nilai tertinggi untuk kepadatan relatif ada pada stasiun II.

Table 5. Hasil Perhitungan Nilai Kepadatan dan Kepadatan Relatif Ikan Layur (Trichiurus lepturus L) di Perairan Pantai Desa Passo.

\begin{tabular}{lccc}
\hline & Stasiun I & Stasiun II & Stasiun III \\
\hline Kepadatan & 1 & 1,90 & 1,58 \\
Kepadatan Relatif & 22,3 & 42,4 & 35,2 \\
\hline
\end{tabular}

Terlihat pada tabel bahwa, nilai kepadatan tertinggi pada stasiun ke-2 yaitu dengan nilai sebesar 1.90 dan memiliki nilai kepadatan relatif dengan persentase sebesar $42,4 \%$. Nilai yang didapat pada stasiun ke-2 sangat jauh berbeda dengan nilai kepadatan yang didapat pada stasiun ke-1 dan ke-3. Dengan perbedaan nilai kepadatan yang didapat, dipengaruhi oleh suh, dan juga kondisi laut yang tak menentu, yaitu kondisi pantai, ombak dan sebagainya.

\section{d. Hasil Perhitungan}

Kelimpahan Trichiurus lepturus $\mathrm{L}$.

Seiring dengan hasil nilai kepadatan dan kepadatan relatif yang telah dijabarkab pada tabel 4.4. Hasil perhitungan nilai Kelimpahan yang ditunjukan pada tabel 4.6 juga mengemukakan bahwa nilai kelimpahan tertinggi yang dipeoleh pada lokasi penelitian di Perairan Pantai Desa Passo terdapat pada stasiun II dengan nilai kelimpahan sebesar 2,64. 
Table 6. Hasil Perhitungan Nilai Kelimpahan Ikan Layur (Trichiurus lepturus L) di Perairan Pantai Desa Passo.

\begin{tabular}{lccc}
\hline & Stasiun I & Stasiun II & Stasiun III \\
\hline Kelimpahan & 1,39 & 2,64 & 2,19 \\
\hline
\end{tabular}

Dengan adanya kepadatan tertinggi yang didapat pada ketiga stasiun penelitian ini yaitu pada stasiun ke-2 maka hal yang demikian juga mempengaruhi terhadap nilai kelimpahan ikan Trichiurus lepturus L. di lokasi tersebut. Nilai kelimpahan tertinggi diperoleh pada stasiun ke-2 dengan nilai yang didapat sebesar 2,264. Hal ini membuktikan adanya keterkaitan antara kepadatan dan kelimpahan, dimana kelimpahan suatu spesies dapat terjadi dan dapat dilihat dari nilai kepadatan spesies tersebut.

Banyak faktor yang mempengaruhi nilai Kepadatan dan Kepadatan Relatif suatu spesies, seperti faktor ekologi dan biologi. Faktor ekologi adalah kemampuan beradaptasi, substrat yang mendukung spesies-spesies untuk hidup dan faktor alam lainnya.

\section{a. Hasil Perhitungan Pola Sebaran Trichiurus lepturus L.}

Dari hasil penelitian di Perairan Pantai Desa Passo dan hasil perhitungan yang telah dilakukan, maka dapat dilihat pada Tabel 4.7 diperoleh hasil perhitungan nilai Pola Sebaran tertinggi ada pada lokasi penelitian stasiun II dengan nilai sebesar 0,539 .

\section{Table 7. Hasil Perhitungan Nilai Pola Sebaran Ikan Layur (Trichiurus lepturus L) di Perairan Pantai Desa Passo.}

\begin{tabular}{lccc}
\hline & Stasiun I & Stasiun II & Stasiun III \\
\hline Pola Sebaran & 0,148 & 0,539 & 0,373 \\
\hline
\end{tabular}

Faktor-faktor yang mempengaruhi pola penyebaran dalam suatu spesies antara lain adanya interaksi satu dengan yang lainnya seperti predator, parasite, penyakit dan ketersediaan makanan (faktor abiotik). Pada hasil penelitian yang telah dilakukan di perairan Pantai Desa Passo, maka diperoleh hasil persebaran ikan layur tertinggi pada lokasi penelitian ke-2 dengan nilai sebesar 0,539 . Sedangkan lokasi terendah ada pada lokasi penelitian stasiun ke-1 dengan nilai pola sebaran sebesar 0,148 .

Pola sebaran umumnya berhubungan dengan cara hidup biota, reprodusi dan penyebarannya, serta pengaruh faktor lingkungan. Pola sebaran dapat berupa (khusus untuk hewan), dipengaruhi oleh kondisi setempat dan oleh sifat-sifat interaksi atau asosiasi dengan biota lainnya.

\section{KESIMPULAN}

Hasil penelitian menyimpulkan bahwa nilai kepadatan, kelimpahan serta pola distribusi ikan layur yang tertinggi terdapat pada stasiun ke-2. Dengan nilai yang diperoleh, maka dapat dikatakan bahwa populasi ikan layur di perairan Desa Passo masih cukup baik. Populasi ikan layur akan terjaga bergantung pada kondisi lingkungan, nutrisi, dan aktivitas masyarakat di daerah tersebut.

\section{DAFTAR PUSTAKA}

Abubakar S.K, 2011. Struktur Komunitas Echinodermata Pada Zona Intertidal Di Gorontalo. Jurnal Penelitian Dan Pendidikan, Vol. 8(1): 51-53.

Effendi, 2003. Telaah Kualitas Air Bagi Pengelolaan Sumberdaya dan Lingkungan Perairan. Penerbit Kanisius; Yogyakarta.

Mukhtasor, 2007. Pencemaran Pesisir dan Laut. Pradnya Paramita: Jakarta

Romimohtarto, K.S. Juwana, 2001. Biologi Laut: IImu Tentang Pengetahuan Biota Laut. Penerbit Djambatan. Jakarta.

Suharti, R. S. Metode sampling ikan karang; editor Ed. 1, Cet. 3. - Jakarta: Bumi Aksara, 2013. Laut Nusantara. Penerbit Djambatan. Jakarta. 